\title{
ADePT (algorithm for decision-making after pilot and feasibility trials): a decision aid for progression from feasibility study to main trial
}

\author{
Carol Bugge ${ }^{1 *}$, Brian Williams², Suzanne Hagen ${ }^{3}$ \\ From 2nd Clinical Trials Methodology Conference: Methodology Matters \\ Edinburgh, UK. 18-19 November 2013
}

\section{Background}

Complex intervention guidance advocates pilot trials and feasibility studies as part of a phased approach to development, testing and evaluation of healthcare interventions. In this paper an example of a feasibility study and pilot trial for a randomised controlled trial (RCT) of pelvic floor muscle training for prolapse is used to explore challenges for progression to main trial.

\section{Methods}

A four-centre feasibility study including pilot trial aiming to randomise 50 women with prolapse of any type or stage and who had had a pessary successfully fitted. We used published methodological categories to classify and analyse the problems that arose in our feasibility study. Subsequently we sought to locate potential solutions that might minimise the trade-off between an explanatory and pragmatic main trial.

\section{Results}

The feasibility study pointed to significant potential problems in relation to participant recruitment, features of the intervention, acceptability of the intervention to participants and outcome measurement. Finding minimal evidence to support our decision-making regarding the transition from feasibility work to a trial, we developed an algorithm (ADePT; Algorithm for Decision-making after Pilot and feasibility Trials) which we subsequently used as a guide. The algorithm sought to: 1) encourage systematic identification and appraisal of problems and potential solutions; 2) improve transparency of decisionmaking processes; and 3) reveal tensions that exist

${ }^{1}$ University of Stirling, Stirling, UK

Full list of author information is available at the end of the article between choices which lead to a pragmatic versus explanatory trial.

\section{Conclusions}

We have developed a decision-support tool that may aid future researchers to identify the most appropriate solutions to problems identified within pilot and feasibility studies.

\section{Authors' details}

${ }^{1}$ University of Stirling, Stirling, UK. ${ }^{2}$ Nursing, Midwifery and Allied Health Professions Research Unit, University of Stirling, UK. ${ }^{3}$ Nursing, Midwifery and Allied Health Professions Research Unit, Glasgow Caledonian University, UK.

Published: 29 November 2013

\section{doi:10.1186/1745-6215-14-S1-019}

Cite this article as: Bugge et al:: ADePT (algorithm for decision-making after pilot and feasibility trials): a decision aid for progression from feasibility study to main trial. Trials 2013 14(Suppl 1):O19.

Submit your next manuscript to BioMed Central and take full advantage of:

- Convenient online submission

- Thorough peer review

- No space constraints or color figure charges

- Immediate publication on acceptance

- Inclusion in PubMed, CAS, Scopus and Google Scholar

- Research which is freely available for redistribution 